\title{
ISLAM IN GANTARANGKEKE: The Encounter of Cultural Identities
}

\author{
Sabara \\ Researcher at Balai Litbang Agama Makassar \\ Jalan.AP. Pettarani No 72 Makassar \\ Email: barackefilsafat@yahoo.co.id
}

\begin{abstract}
This article is a study of Islamic relations and local traditions in this case is the Islamic tradition of the Gantarangkeke indigenous people, Bantaeng Regency as a locus. The research problem is how is the history of the Islamic encounter with Gantarangkeke locality and its influence on the beliefs and traditions of the Gantarangkeke people ?. This study belongs to the category of qualitativedescriptive field research, using a historical, philosophical, social, cultural, and descriptive-critical analytical approach. The local tradition of the Gantarangkeke community has grown long before Islam entered their territory. The tradition is rooted in the belief of the Patuntung religion which is the ancient belief of the pre-Islamic Gantarangkeke community. The local tradition is institutionalized at the Pajukukang traditional ceremony which is held every year and has several series of events, namely assulukang pangngajai, akkawaru, if ri pajukukang, and angnganre toballa'na. The encounter of Islam and local traditions gave birth to a model of cultural struggle in which Islam as a teaching that came from the outside and of a global nature was brought into the realm of the locality of the Gantarangkeke tradition. This then gave birth to the concept of Sallang religion as a meeting point between patuntung and Islamic beliefs. The concept of Sallang religion later became the basis for the locus and forms of the struggle of the culture. Cultural struggles enter the locus of the belief system, the socio-cultural system, and the rite system and the symbolic meaning of tradition. The cultural
\end{abstract}


struggle gave birth to four forms of cultural and religious relations, namely negotiation, compromise, syncretism, and cultural acculturation. From this cultural struggle, the local culture model of Gantarangkeke was unique and unique.

Keywords: Local Islam, Cultural Meetings, GantarangkekeBantaeng

\section{INTRODUCTION}

In religious studies there are two aspects that must be distinguished, namely what is called the general pattern and particular pattern. General pattern is something that is sure to exist in every religion, beyond the capacity of its adherents, such as: belief, ritual, holy text, leadership, history and constitution, and morality, this is what is called the fundamental structure of religion. A researcher must be objective in reviewing this matter. The problem is that religion is not constant but always adapts to the social conditions of the community, in the sense that they influence each other.

Islam on the one hand is a global power that has a common fundamental doctrine that unites various Muslims who are spread in various regions of the world. But on the other hand, Islam still provides an opportunity for various forces of local culture to actualize themselves and acculturate, and unite with Islamic doctrine and finally display unique Islamic characteristics in each region. In other words, as a universal religion, Islam is a religion that is not rigid or can always adjust / contextualize itself with the situation and conditions faced according to its locus and tempus. 
Therefore, when talking about Islam, besides positioning Islam as a religion, we must classify it into three categories; theological, political and cultural views. Islam as a power of religion that has global characteristics that can be accepted by humans in every space and time. However, on the other hand Islam with a very large number of followers entered various regions of the region. So that its global characteristics seem to disappear into various local forces that it enters.

The Islamic and socio-cultural encounter of the archipelago community in general presents Islamic accommodation that comes from local values. Islam that comes in the midst of communities that already have a belief system and various value systems, also try to accommodate these values. In Java, for example, the relationship between Islam and local culture, both explicitly and implicitly, there was an effort to accommodate each other between Islamic values and pre-Islamic Javanese values. These efforts have taken place since the early Islamic muballighs in Javanese land, such as Wali Songo, which was later practiced in the daily lives of Javanese Islamic communities.

The encounter between Islam and local traditions in South Sulawesi is not entirely acculturative in nature, but in many cases there is a cultural negotiation process and even encountering cultural processes, where local culture still seems dominant, or in other languages, when the Islamic culture enters, local culture does not lose its total identity. Local culture with its various forms and systems of belief and 
traditions still persists and does not necessarily position inferiorly in the face of the coming Islamic culture. So that local culture remains sustainable, but undergoes a cultural transformation and gives birth to a new cultural model that is the result of a combination of Islam and local culture that has existed before.

The process of cultural encounters between Islam and the local culture of Gantarangkeke is interesting to study and examine more deeply. The process starts from the encounter between the arrival of Islam and local culture, then the interaction between cultures, followed by cultural struggles in the form of indigenousism, negotiations, even cultural conflicts to the transformation of traditional forms and systems, and the presence of Islamic local models without stripping off his local identity. Based on this, this study focuses on research problems; history of the encounter of Islam with Gantarangkeke locality and its influence on the beliefs and traditions of the Gantarangkeke community

\section{THEORETICAL REVIEW}

\section{Locality in the Identity Theory Perspective}

As social beings, every human being identifies himself based on his community. Such self-identification is part of the process of internalization of the beliefs of the people. As said by Castells that human identification of the social environment is a process of internalization and construction of the meaning of the internalization. Locality in identity theory is usually discussed in the context of essentialism and 
anti-essentialism. The search for identity based on essentialism means that there must be something universal and eternal. Essentialism assumes that descriptions of self reflect an essential identity. Based on this, there is a different essence between one local community and another local community, and between "local" and "global". Conversely according to anti-essentialist ideas, identity is a discursive construction and changes its meaning according to space, time, and usage. In this study, researchers took the perspective of these two views. That the identity of a locality is an essentialist that is significantly different from other globalities or localities. However, these differences are not within the framework that is vis a vis. There is still space to fill each other between each other. At the level of meaning it is very possible to change according to the situation of space and time.

Locality as an identity that is close to a local community based on certain ethnic or cultural, is an embedded identity. This identity is firmly rooted in every member of the community, and does not necessarily escape because of a particular tendency or influence. Ethnic and cultural identity is transformed from one generation to another in hereditic. Cultural identity is an identity that is built intentionally in connection with a set of beliefs and culture as the identity of the former is more organic. On its journey the meaning and even modes of identity itself continue to undergo the reconstruction process in accordance with the context at hand. The reconstruction process is basically a process for locality to strengthen its identity. 


\section{Islam and Locality}

According to Ajid Thohir, talking about Islam in a historical perspective, Islam should be separated into three categories, namely as religion, state, and culture. The ability of Islam, absorbing all the traditions that come from various regions it enters has made Islam increasingly rich and diverse. Thus, this will further strengthen Islam as a universal, contextual, and always after all time and place. According to Masnun Tahir, the struggle of Islam with local treasures, made Islam so multi-faceted. When Islam encounters a variant of local culture, what immediately takes place is a variety of symbiotic processes that enrich each other. Finally a variety of variants of Islam emerged, which showed that Islam always had a local color when approaching a community. Islam does not come in an offensive mode and pretends to finish off the local variants it faces, on the contrary, Islam is present to then enter and diffuse to give influence to the face of the culture of a community without losing its identity.

Regarding the context of the struggle of Islam and local culture, Djoko Suryo mentioned four possible patterns of relations between Islam and local traditions. The first pattern is Islamization, which is when the results of the cultural struggle between the two are dominated by Islam. The second pattern is indigenousism, when Islam and local traditions integrate and produce a unique cultural synthesis. The first and second patterns are patterns of cultural integration with different variations. The third and fourth patterns are negotiations and cultural conflicts. According to 
Ahmad Baso, the struggle for the representation of culture and negotiations will eventually break the hegemony and dominance, the two variants of the tradition can be integrated into the indigenous model.

\section{RESEARCH METHODS}

This research is field research. This type of research is qualitative-descriptive, which aims to find an explanation of the encounter of Islam and local traditions in the Gantarangkeke indigenous people of Bantaeng district. The approach used is a phenomenological approach that seeks to understand the meaning of events and their relationships to ordinary people in certain situations. This approach, among others, was influenced by Max Weber who emphasized verstehen, namely the interpretive understanding of human understanding. Methods of collecting data through interviews, observation, and document studies.

In terms of data processing techniques, two techniques were used, namely, first identifying data as the results of interviews obtained in the field from several sources related to research. Second, the conclusions are based on data that has been analyzed as a result of the study. The technique used when getting data in the field is a qualitative data analysis technique. Descriptive analysis techniques carried out after the data collected from the field can be carried out in three cycles of activities, as mentioned by Miles and Haberman, namely the stages of data reduction, display (presentation) of 
data, and conclusions. The following are the three stages of data analysis in this study:

\section{FINDINGS AND DISCUSSION}

History of the Islamic Encounter and the Gantarangkeke Tradition

Archeological evidence has not yet been found which shows that there is a special Islamization process for the Gantarangkeke community. There has been no evidence of the ancient tombs of Islamist disseminators or documentary traces of the entry of Islam in Gantarangkeke. Are there special muballighs that come to spread or teach Islam in Gantarangkeke, there is no corroborating evidence and records.

Traces of the tombs of Islam spreaders in Lembang China and in Kampung Letta, Bantaeng sub-district are all far outside the Gantarangkeke area. For example, the graves of La Tenriruwa and Sheikh Nurun Baharuddin in Bantaeng and the tomb of Datuk Kalimbungan in Bissapu sub-district. Based on this, the researchers then concluded that the Islamization process entering Gantarangkeke coincided with Islamization in the entire kingdom of Bantaeng. This is because in the process of Islamization, the kingdom of Gantarangkeke was lost and only became one of the gallarang areas in the kingdom of Bantaeng. Islamization in Gantarangkeke is directly related to the Islamization of Bantaeng as a whole. 
Based on historical-archaeological data that shows the absence of special figures as spreaders or instructors of Islam in Gantarangkeke. It can be concluded that Gantarangkeke's position in terms of Islamization in Bantaeng is far from the center or is on the outskirts of Islamic da'wah. This marginal position is further strengthened by the geographical location of Gantarangkeke which is far from the center of the Bantaeng kingdom because it is in the interior. Until the 2000s, access to Gantarangkeke was still very difficult, because road facilities had not yet been built, motorized vehicles were difficult to enter into the area. This condition made it so that Islam that entered the Gantarangkeke community from the beginning of its spread until the independence period was not as Islam was accepted at the center of dissemination and teaching.

There is something interesting about the conception of Gantarangkeke traditional leaders regarding Islam and its local traditions. For them Islam is not something that "comes" but "comes" from that place. For the people of Gantarangkeke, Islamization is not a process of entering new values which then eliminates the old values adopted. They believe that they have embraced "Islam" before Islam came from Arabia. For them, the substance or essence of Islam already exists in the Gantarangkeke community long before Islam came. They came to understand Islam as Shari'ah Islam which came to fulfill the value of the essence they had before.

Through this conception, substantially, the Gantarangkeke community would assert his social history 
about the process of Islamic encounter and their local traditions. Why do Gantarangkeke people not reject Islam because for them Islam is not something new to them. Islamic meetings and local traditions are not an encounter between Islam and something else, but the encounter between values and teachings that are substantially the same, differ only in the realm of position. Islam comes as interpretation of the Shari'ah while the "Islam" that comes from their region is the essence of Islam. As some of the indigenous peoples say to the researchers, that religion they are basically the Sallang religion (salvation). The concept of Sallang religion is not much different from the Islamic religion, except from the aspect of the Shari'a.

There is a narrative spoken by Siu bin Sikau bin Karaeng Baso about the beginning of the introduction of the Gantarangkeke community in the Tauhid sentence (La Ilaha Illallah). According to the story of the Gantarangkeke community, the Tauhid sentence was first taught by a young man who got the sentence in the top of his tafakkur. The youth then taught them to the community. When the young man did tafakkur and who was actually the young man, there was no clear answer, but it was believed that the young man was a native of Gantarangkeke who was still a descendant of Karaeng Gantarangkeke. Through this Tauhid sentence, the people of Gantarangkeke then accepted and professed the religion of Islam. Although basically the Tauhid sentence taught by the youth is essentially believed by the Gantarangkeke community in their religion called Sallang 
religion. That's why the sentence is so easily accepted by the Gantarangkeke community.

In the view of the researcher, the narrative about the acceptance of Islam spoken by indigenous peoples Gantarangkeke is a form of culture to "deny" the full penetration of normative Islam that will enter their territory. This is done as part of efforts to maintain local traditions without having to reject the Islamic religion that comes to them. This cultural politics is played by Gantarangkeke's indigenous peoples throughout the history of their interaction with Islam and makes their local traditions still exist today. Gantarangkeke's position on the periphery of the spreading and teaching of Islam makes this tactic more effective. Access to Islamic knowledge that can be said to be lesser also strengthens their position on local traditions, although at the same time they still reject it if it is not said as a Muslim.

Through other perspectives according to the researcher, the narrative built on the acceptance of Islam by the Gantarangkeke community as mentioned above. It is a form of identity politics in order to maintain their local cultural identity in the face of the arrival of global Islam. Their cultural tactics do not try to vis a vis and be confrontational, but are accommodative and compromising to then negotiate culture between their location and the nature of the globality of Islam. Through narratives about the sallang religion and the Gantarangkeke youth who get the Tauhid sentence through the peak of the tafakkur it contains the meaning of efforts to build harmony with the globality of Islam while still 
showing their local identity. According to eidos researchers of the narrative is a feeling of superiority in their identity which, although local, is equivalent to the global religion of Islam. Through these narratives they build an image of equality and the substance of cultural values between Islam and their locality.

Furthermore, to further elaborate on the pattern of meeting Islam and lokaliats Gantarangkeke researchers tried to use the central circumference method (central nexus) in the approach to social history. That is, history is revealed from the point of history in the middle and begins with a description of synchronicity (history which examines social phenomena that are widespread in space, but limited in time) and then diachronically (history which examines symptoms that elongate in time, but limited in space) indicated growth. This is inseparable from the history of Gantarangkeke Islamization which is part of the Islamization of the Bantaeng region as a whole, and Gantarangkeke is positioned as a peripheral region. Therefore, reading the social history of Gantarangkeke Islamization is also associated with the reading of the social history of Islamization in the central region of Bantaeng.

According to La Sakka, since the beginning of the spread of Islam in Bantaeng always received supervision from the kings so that relations with adat and the implementation of Islamic law together. The scholars often preach the rules of Shari'a regarding the illegitimacy of an act, but they do not go through extreme ways that can shake the joints of people's 
lives. Islamic advocates received protection from Karaeng (king), but in addition to protection from Karaeng they also received supervision in carrying out their duties so that they did not offend the customs of the people so that between adat and the implementation of Shari'a did not collide which could disrupt the social system.

The encounter of Islam and local culture in Bantaeng generally, as well as in Gantarangkeke in particular, shows that Islamic missionaries do not necessarily negate the elements of local culture. This condition seems to have evolved at the beginning of Islamization in Bantaeng, as in other regions in South Sulawesi and in Indonesia in general. Apparently, at the beginning of the dissemination of Islam in Bantaeng at first it was invited to change from the level of essential beliefs, namely the oneness of Allah and the Recognition of Muhammad as an envoy, while in the aspect of Shari'a it still provided adaptive space. This assumption is based on the many archeological remains that show the existence of Islamic sinkretsme. The elements of local culture remain alive in the early Muslim community. The shift of Shari'a values continues along with the increasing understanding of the community about the teachings of Islam, such as the increasing content of tombstone encryption values in the La Tenriruwa complex in the phase of the 19th century. So that the aspects considered to be able to direct polytheism naturally eroded little by little. This assumption, as reflected in some archaeological remains in mosques, palaces and tombs. Indicators of change and an increase in understanding of the 
teachings of Islam are calligraphy inscriptions that are increasingly weighty and the quality of the arts is getting higher.

The history of Islamization and the encounter with local traditions in Gantarangkeke, it seems that initially there were integrative patterns carried out to adapt to local communities who still held strong ancestral traditions. Incoming Islam does not directly intersect with local traditions, which even some are contrary to Islamic teachings, such as the tradition of drinking ballo (local liquor) and chicken combing. Slowly but surely, these behaviors that clearly conflict with Islamic law began to disappear from the habits of society. Nevertheless, certain traditional customs such as the worship of saukang and kalompoang and preIslamic heritage ceremonies are still faithfully carried out, although in some aspects they have adapted to Islamic teachings.

The Gantarangkeke community treats the teachings of Islam as obedient in practicing customs. This is because the acceptance of Islam by them at first did not change too much social values and norms and customs that existed in the community. Since the beginning of the development of Islamic teachings, matters relating to customs such as worship of kalompoang and saukang., Giving offerings to saukang after harvest and other habits originated from the time before Islam did not get a ban from the spreaders of Islam who came. Harvest parties that take place in Saukang, according to adat, still need to be maintained because they are a sign of the 
people's gratitude for their harvest. The same is true of the tradition of belief in ancestral spirits, even though Islam has been embraced by the Gantarangkeke people, but the belief in ancestral spirits does not disappear completely.

The pattern of Islamization that is quite adaptive to local traditions, makes many local traditions in Gantarangkeke still survive today. In the end local traditions and Islamic teachings went hand in hand in the practice of the daily life of the Gantarangkeke people. This is a form of cultural negotiation carried out, resulting in a pattern of interaction between Islam and local traditions which can be said to lead to practices that tend to be syncretic.

It is different from the Kajang customary community who from the beginning accepted Islam only accepted Islam in a formal manner, but did not implement it in daily shari'a practices such as prayer, fasting, hajj, and others. The Gantarangkeke indigenous people remain in the openness of accepting Islam as an individual practice of worship. However, the practice of traditional rituals continues in synergy with their Islamic practices. This happened because of a long historical social struggle, until finally Islam and local traditions then shared space in the practice of the daily lives of the Gantarangkeke people.

During the DI / TII rebellion led by Kahar Muzakkar the Gantarangkeke indigenous people were in difficult times and full of threats. They were not free to carry out their traditions because of intimidation and even violence committed by DI / TII soldiers. Many customary materials 
were burned including their lontara texts. The stigma of being polytheists made them the DI / TII soldiers' months which indeed had a mission to eliminate all forms of traditional practices that were contrary to their Islamic understanding. These difficult times were told by one of the adat leaders, that at that time they had to hide into the forest to avoid attacks from "mobs" (DI / TII soldiers). Many customs and inheritance cannot be saved anymore. However, the pressure in these difficult times continued with patience, until the DI / TII rebellion ended and they could freely re-establish their traditions.

In the subsequent development of the Gantarangkeke indigenous people then they were able to carry out their traditions despite still being accused of polytheism from other Muslim communities. Stigma as a traditional, exclusive, and abangan society is compounded by development that does not touch their territory. They seem to be marginalized because they are almost untouched by equitable development, such as road access, electricity, education and others. This condition continued until the 2000s. With these conditions, the Gantarangkeke indigenous people remain loyal to their local traditions, although they still affirm Islam as their formal religion.

After the rolling reforms and the strengthening of the enforcement of Islamic law, Bantaeng district is one of the places where the implementation of "Islamic law" in the style of the masses known as Forbes (Joint Forum) is carried out "well". Because of its formalism, the Joint Forum is very anti- 
polytheistic. Although not confrontational and indirect, the Joint Forum once threatened indigenous communities in Gantarang keke. It is said that one of the members of this community had been accused of stealing and therefore was obliged to be punished. The accused was chased to the location of the custom, he was threatened with death and even the houses there would be burned. Fortunately, the theft charges did not prove that they (Forbes) failed to carry out their intentions to execute.

In recent years, the Gantarangkeke indigenous people have been free to carry out their traditional traditions. The traditional parties that are held now are increasingly lively due to access to roads that have been well built and the electricity that has entered their territory. Every Pajukukang traditional party is held, thousands of people come to meet the location of the event, even the local government takes part. This phenomenon does not mean that the stigma against them is immediately lost, the stigma against them still exists among the Bantaeng Muslim community, especially those who understand modernism. One time the researchers talked with several young Islamic activists from an Islamic organization in Bantaeng, they considered that the indigenous Gantarangkeke community was a customary society that still practiced cultural behavior that was contrary to Islamic teachings. They also agreed when the researchers asked whether they were of the view that the cultural behavior of the people of Gantarangkeke was idolatrous. 


\section{Islamic Influence in Community Trust}

The pre-Islamic beliefs of the Gantarangkeke people are Patuntung's beliefs, namely the common beliefs held by Makassar ethnic communities along the southern coast. The points of patuntung trust are the belief in the figure of Karaeng Loe, tomanurung, belief in ancestral spirits that occupy certain places, especially on the summit of Mount Lompobattag and Bawakaraeng, and belief in souls and supernatural powers that exist in places or objects certain items, as well as trust in the butta pocci (land center) located in Gantarangkeke. After Islam came, this belief did not necessarily disappear, but Islam as a new belief gave some influence on the structure of trust in the Gantarangkeke community.

After embracing Islam, the Gantarangkeke people called their old beliefs the name of the Sallang religion and no longer the Patuntung religion. The concept of Sallang religion is the result of the influence of Islamic beliefs that came to them. In general, the main points of old trust did not disappear but only experienced a shift, for example the belief in the figure of Karaeng Loe as the figure of the Great God was replaced by a belief in Karaeng Allah Ta'ala and a belief in the prophethood of Muhammad. Even so, the figure of Karaeng Loe still gained a place in the realm of the trust of the Gantarangkeke community. The traditional tradition that was once a ritual aimed at worshiping the figure of Karaeng Loe, has now shifted into a ritual of gratitude to God even though the figure of Karaeng Loe still gets a place in the ritual. 
However, Karaeng Loe's position as a worshiped main figure experienced a shift and was replaced by Allah as the main object of worship.

Before Islam came, the Gantarangkeke people believed that tomanurung which descended on their area was the first to know or human. This belief then "compromised" with the Islamic belief about the prophet Adam as the first man. Finally, although they still believe in the figure of Tomanurung as a beginning of their community, their belief in the figure of the Prophet Adam is still believed to be the beginning of the existence of humans on earth. The existence of tomanurung is still associated with the existence of the prophet Adam as truly the first human being. The existence of tomanurung as the incarnation of Karaeng Loe or the Great God is still believed along with the belief in the prophet Muhammad peace be upon him as the last prophet and complete man and belief in the prophet Adam as the first man.

Trust in Ganatrangkeke land as the first land and belief in pocci butta as the center of the earth is still embraced by Gantarangkeke society. Once Islam enters, faith in the land of Ganatarangkeke as the first land and center of the earth is then pledged to the capability of the land of Mecca as the center of the earth. Land of Gatarangkeke, which was once referred to as Tanah Loe, because here is Karaeng Loe, which appears to be a landmark, is believed to be the land of pallaman, which is one of the sources of the land of Adam as made. After Islam entered, the belief in pocci butta in 
Gantarangkeke was integrated into the belief in the land of Mecca as a pocci butta in Islam. Although the belief in pocci butta in Ganatarngkeke is not completely lost, it is believed to be part of the center of land in Mecca. The Loop of the Land of Loe (Gantarangkeke) is linked to a source of land for the creation of the prophet Adam.

Belief in ancestral spirits that was once adopted strongly and implicated in some rituals of worship of ancestral spirits after the entry of Islam also experienced a shift. Although belief in ancestral spirits in the mountains of Lompobattang and Bawakaraeng is not completely lost. However, with the advent of Islam, the beliefs have slightly adjusted to the basic beliefs of Islam regarding the death of the deceased. The spirits of the ancestors were no longer worshiped, but there were special rituals dedicated to ancestral spirits as a form of breeding, praying, and demanding blessing and protection from the noble spirit of glory.

The beliefs of the Gantarangkeke society that are animism and dynamism embraced, namely the belief in the existence of the souls and the supernatural powers of certain places or objects and it gives the human influence. After the advent of Islam the faith has been adjusted to the basic doctrine of Tauhid. Although it has embraced Islam, the people still believe in the soul and the strength, but with the influence of Islam, the belief in the existence of the soul and supernatural powers is still relied upon to belief in Allah swt. 
Tauhid as a basic doctrine in Islamic beliefs is accepted and remains the basis of the Ganatrangkeke's religious structure and system of society. So long as the old beliefs and old rites which are meant to be worship rituals are still not lost, but have been adjusted to the basic doctrine of Tauhid, which is the way to associate God with others. Belief in Allah as the only God is finally a guide to the structure and belief system of the indigenous people of Gantarangkeke.

According to the narrative, the event carried out was only a form of prayer and gratitude only to Allah. The concept of the Asmaul Husna or the name of Allah which amounts to 99 is associated with their tradition. According to the juku, there is still one more name for Allah, namely the 100th name that is still hidden. This 100th asthma is the target that is sought in this pajukukang tradition. In essence, the prayers that are read and the rites carried out are to look for the hidden name of Allah in order to perfect the name of Allah to be 100 . When the author asks what the name of Allah is the 100th, juku only answers it is confidential and only can be solved through this pajukukang ritual.

The Influence of Islam in Tradition and its Symbolic Meanings

The influence of Islam on the traditions of the Gantarangkeke community is evident in all the rites of the traditional traditions that they carry out. Although the forms of pre-Islamic traditional ritual traditions are not lost, with the arrival of Islam there has been a lot of influence. These influences range from ritual orientation, prayers, the meaning 
of the essence of rituals, to profane aspects, namely entertainment which enlivens traditional party events. Islamic arrivals eliminate some aspects of tradition that are contrary to Islamic teachings and maintain some other aspects of tradition., but it fills the substance with the values, principles and teachings of Islam. The influence of Islam on the local tradition of Gantarangkeke is seen in the whole series of pajukukang traditions, starting from pangngajai, akkawaru, if ri pajukukang, to pucnak angnganre to balla'na. Traditional forms which are inherited from the pre-Islamic tradition are still visible in the whole series of ceremonies, except that with the arrival of Islam, the ritual series of the traditional ceremonies then adjust to the basic teachings of Islam, in this case Tawheed and Shari'a.

The influence of Islam on the structure and belief system of the Gantarangkeke community certainly has implications for the influence of Islam on their traditions. The pajukukang tradition which was previously fully intended as a cult of Karaeng Loe and a number of other traditional rites aimed at the beginning of ancestral spirits and the soul and supernatural powers in certain places or objects. Substantively, there is a shift in orientation towards rites which is aimed primarily at God Almighty. This shift has implications for changes in prayer texts or spells read in these rituals, the name Allah Almighty and the Prophet Muhammad filled the "main room" in the spell and the prayers they read. The names of Allah and the prophet Muhammad are always mentioned in their prayers or mantras if they are associated 
with hope in salvation and sustenance and rejection of reinforcements and disturbances from evil spirits.

Before starting the series of rituals, both led by pinati, puanna, even juku, the teacher's teacher, and other adat stakeholders always begin with the basmalah greeting as an opening ritual. When the traditional ritual of prayer that is most often offered is a prayer that mentions the name of Allah and the Messenger of Allah which contains hope that the whole community will always be given health and cheap sustenance. Sayings of hamdalah and prayer of the prophet are often mentioned in their prayers, although in general they still use the Makassar language Konjo dialect.

The influence of Islam on the Gantarangkeke tradition, is seen in the timing of their traditions, starting from pangngajai to angnganre toballa'na. Before Islam entered, the calculation of their calendar to determine when the event began was very simple, namely by burning kanjoli every night. If the number of burnt kanjoli has been the same as the number of days in a month and the number of months in a year, the series of ceremonies begins. Thus the calculation of the time of year is $30 \times 12=360$ days, a very simple calculation by equating the number of days in each month.

After Islam entered, the annual ritual was carried out once a year but the timing was no longer using the traditional system but followed the system of the Hijri calendar. According to Thomas Gibson, citing reports from Western researchers who have come in Gantarangkeke around the 19th century, such as Goodsward, the pajukukang tradition is 
carried out by following the entry of the month of Ramadan. As such, the pajukukang tradition carried out by each Sya'ban has been going on for a long time, or since the entry of Islam into Gantarangkeke. The peak of the pajukukang tradition that is carried out every month in the Shafi'ah is also always associated with a ceremony to welcome the coming of the holy month of Ramadan.

The influence of Islam on the tradition of the Gantarangkeke people, especially the tradition of the pajukukang ceremony is the replacement of several events which become entertainment to fill the festivity of parties which conflict with Islamic law to entertainment programs that do not conflict with Islamic law. Gambling games, drinking ballo (traditional liquor), and cockfighting are replaced with other entertainment such as a'sempa, a'lanja (calf fighting), a'manca, regional dances, even qasidah music.

The arrival of Islam also has an influence on the way the Gantarangkeke people live and give symbolic meaning to their traditions. The main postulate is that all the traditions they do do not conflict and even conform to Islamic teachings. They also interpreted that the traditions they kept preserving were part of the ritual to achieve one of the elements of the essence of Islam, for example with the view that the tradition they did was to seek the essence of Allah's asthma through the discovery of God's 100th asthma

Every symbol of tradition and ritual that they do after they enter Islam is always given a synergistic meaning with symbolic and substantive meanings derived from Islamic 
teachings. The concept of Sallang religion, which they believe to be their basic belief since the days of their ancestors, symbolically implies a substantive effort in building substantive relations with Islam. By constructing the concept of Sallang religion, the local community of Gantarangkeke builds an effort to symbolic their traditional beliefs with the coming religion of Islam, so that acceptance to Islam does not make them abandon their old beliefs .

In substantively, the Gantarangkeke community interpreted the whole ritual of their tradition as a form of thanksgiving and servitude to Allah alone as taught in Islam. The very symbolic appreciation of the rituals of the Gantarangkeke community is the symbol of the number 7 which is the number of rounds of incense at the time of the ritual of akkawaru, angnganre to balla'na to the peak ritual of Karaeng Loe. The number 7 is interpreted according to some number 7 in the teachings of Islam, such as the number of letters in al-Fatihah, the number of tawaf, and so on. The rounded denial of incense is linked to the circumference of the Tawaf at the time of pilgrimage or umrah. The number 7 is particularly meaningful as the number 7 also has a special symbolic meaning in Islam.

The top ritual of the angrily to the ball, which consists of two main rituals, namely angnganre to balla'na itself and the ritual of the Karaeng Loe ritual is adhered to as the substance of the leadership concept in Islam that a leader should prioritize his people than himself. Ritual a; tilili which is a ritual of blessing by the pinati by means of minya 'smell 
to some parts of the face of people who come to balla' lompoa is also appreciated with the approach of Islamic teaching as a symbol of the prayer movement, namely standing motion, bowing, prostration, and sitting.

\section{CONCLUSION}

Islamic meetings and local traditions Gantarangkeke is not a meeting between Islam and something else, but the encounter between values and teachings is substantially believed to be the same. The history of Islamization and the encounter with local traditions in Gantarangkeke, initially appears to be integrative patterns that are being made to adapt to local communities who still hold strong ancestral traditions. The Islamization pattern adaptively adapted to local traditions, making many local traditions in Gantarangkeke still persist until now. Ultimately, local traditions and Islamic

teachings coexist in the practice of everyday life of Gantarangkeke society. This is a form of cultural negotiation conducted, resulting in the pattern of interaction between Islam and local traditions which can be said to lead to practices that tend to be syncretized. The presence of Islam gives a lot of influence and also color the construction of local beliefs and traditions of Gantarangkeke society.

Through a long process of cultural struggle between Islam and the locality of Gantarangkeke, it produces a model of local Islamic tradition typical of the Gantarangkeke community that represents the local identity and susbtantif influence of Islamic teachings. The cultural modeling is a local 
identity of the Muslim community Gantaragkeke as a local Muslim community that still exists with its localization. However, on the other hand it shows the real influence of Islam as a universal teaching that comes from a global space of human culture, or at least originating from outside the Gantarangkeke community. The cultural modeling can be seen in almost all of Gantarangkeke's cultural systems, ranging from trust systems, value systems, to rite systems in custom ceremonies that demonstrate the process of distinctive cultural interaction between Islam and the localities of the Gantarangkeke Tradition.

\section{REFERENCES}

Abdullah, Taufik dan M. Rusli Karim (ed), Metodologi Penelitian Agama: Sebuah Pengantar. Yogyakarta: Tiara Wacana. 1989.

Ahmad, Abdul Kadir dkk. Jarak Sosial Sebuah Identitas. Makassar: Idelenggara. 2009.

Akhmar, Andi M (ed). Bantaeng Masa Prasejarah ke Masa Islam. Makassar: Masagena Press. 2007.

Alifuddin, M. Islam Buton: Interaksi Islam dan Budaya Lokal. Jakarta: Badan Litbang dan Diklat Departemen Agama RI. 2007.

Arikunto, Suharsini Manajemen Penelitian. Jakarta: Rineka Cipta. 2007.

Baso, Ahmad. Plesetan Lokalitas:Politik Pribumisasi Islam. Yogyakarta: Desantara. 2002. 
Castells. Manuel. The Power of Identity. Chisester: West Susex:Blackwell Publishing Ltd, 2010.

Gibson, Thomas. The Sun Pursued the Moon:Symbolic Knowledge and Traditional Aubority among the Makassar. Diterjemahkan oleh Nurhady Sirimorok dengan Judul Kekuasaan, Raja, Syeikh, dan Ambtenaar. Pengetahuan Simbolik dan Kekuasaan Tradisional Makassar 1300-2000. Makassar: Ininnawa, 2009.

Gunawan, Imam. Metode Penelitian Kualitatif Teori dan Praktek. Jakarta: Bumi Aksara, 2014.

Koentowijoyo. Metodologi Sejarah Sejarah. Yogyakarta: Tiara Wacana. 2008.

Maunati, Yekti. Identitas Dayak: Komodifikasi dan Politik Kebudayaan. Yogyakarta: LkiS. 2004.

Miles dan Huberman, Qualitatif Data Analisis Beverly Hill: SAGE Publication itd. 1984.

Moleong, Lexy J. Metodologi Penelitian Kualitatif. Bandung: PT Remaja Rosdakarya. 2001.

Said, Muhazzab. "Kajian Akulturasi islam dan Budaya Lokal Bungamale sebagai Budaya Lokal Sulawesi Selatan”, dalam Jurnal al-Fikr Volume 16 Nomor 3 tahun 2012.

Sakka, La. Sejarah islam di Bantaeng. Laporan Penelitian Balai Litbang Agama Makassar. 2013.

Surjo, Djoko dkk. Agama dan Perubahan Sosial: Studi Hubungan Antara Islam, Masyarakat, dan Struktur Sosial Politik di Indonesia. Yogyakarta: LKPSM. 2001.

Thohir, Ajid. Studi Kawasan Dunia Islam. Jakarta: Rajawali Press. 2009. 